\title{
FI-photoinduced Chemiluminescence Method for Diuron Determination in Water Samples
}

\author{
Mónica Catalá-ICardo, ${ }^{\dagger}$ José Luis López-Paz, and Andrea PeÑa-Bádena \\ Instituto de Investigación para la Gestión Integrada de Zonas Costeras, Escuela Politécnica Superior de Gandía, \\ Universidad Politécnica de Valencia, C/Paranimf n 1, Grao de Gandía, Valencia 46730, Spain
}

\begin{abstract}
A new method for the determination of the herbicide diuron, using a flow injection manifold and photoinduced chemiluminescence detection, is presented. The pesticide, in basic medium, was irradiated on-line with UV light $(254 \mathrm{~nm})$ for $53 \mathrm{~s}$. A short discussion about the possible irradiation products is included. The chemiluminescent response of the photoproducts was induced by oxidation with potassium ferricyanide in phosphate buffer at $\mathrm{pH}$ 11.5. The method permitted the quantification of diuron over the $0.1-4.0 \mathrm{mg} \mathrm{L}^{-1}$ range, with a detection limit $(S / N=3)$ of $20 \mu \mathrm{g} \mathrm{L}^{-1}$ when the method was applied directly. However, the use of solid phase extraction (SPE) performed with $\mathrm{C}_{18}$ cartridges allowed us to achieve a limit of detection of $0.4 \mu \mathrm{g} \mathrm{L}^{-1}$ and a $1.5-30 \mu \mathrm{g} \mathrm{L}^{-1}$ dynamic range. The method was successfully applied to the diuron determination in samples of water from different sources (spring, ground, mineral, irrigation, sea and tap waters) with a low consumption of reagents.
\end{abstract}

(Received October 19, 2010; Accepted December 10, 2010; Published March 10, 2011)

\section{Introduction}

Diuron (3-(3,4-dichlorophenyl)-1,1-dimethylurea) is a pre-emergence phenylurea herbicide. It is mainly absorbed by the roots and acts by inhibiting photosynthesis. ${ }^{1}$ Diuron is used in crops and as an algicide in fish farms. However, many aquatic organisms are sensitive to either diuron or its degradation products, some of which are highly toxic, such as 1-(3,4-dichlorophenyl)urea and methylurea. ${ }^{2,3}$ Seagrasses and adult corals ${ }^{4}$ can be affected by diuron concentrations as low as $0.1 \mu \mathrm{g} \mathrm{L}^{-1}$.

Diuron is stable against hydrolysis (at neutral $\mathrm{pH}$ and room temperature) and sunlight, ${ }^{5}$ although it hydrolyzes at acid or alkaline $\mathrm{pH} ; 3,4$-dichloroaniline is the main product, ${ }^{6}$ which is highly toxic. ${ }^{7}$ It is also degraded photochemically ${ }^{8,9}$ and by ozonation. ${ }^{10}$ Diuron is persistently adsorbed to the colloids (half-life up to eleven months); hence it can be used in deep-rooted crops. Likewise, the pesticide can be degraded in the soil by microbial action, which is favored by the presence of organic matter. However, its relatively high solubility in water $\left(40 \mathrm{mg} \mathrm{L}^{-1}\right.$ at $20^{\circ} \mathrm{C}$ ) can led to the aquifers pollution. It is partially adsorbed to the sediments, and its photolytic degradation in surface waters takes place within a few days. It is toxic to humans, causing irritation on contact with the skin and mucous membranes, and it has been shown to be carcinogenic. ${ }^{11}$

Diuron has been included in the European Union's (EU) list of priority hazardous substances. ${ }^{12}$ In order to achieve the required sensitivity and selectivity, analytical methods are often complemented by extraction techniques. The ease and simplicity of solid phase extraction (SPE) systems makes them the preferred extraction method for many authors. ${ }^{13}$ In the case of

$\dagger$ To whom correspondence should be addressed.

E-mail: mocaic@qim.upv.es diuron, different sorbents have been used, particularly $\mathrm{C}_{18}{ }^{14,15}$ and polymers such as $N$-vinyl-pyrrolidone ${ }^{16}$ and poly(styrenedivinylbenzene).$^{17}$

Phenylureas are usually determined by chromatography. As diuron is thermally unstable, it has to be changed into a stable derivative in order to use gas chromatography (GC). For instance, ethyl iodide has been used as an alkylating agent, ${ }^{18}$ as has iodoethane with sodium hydride ${ }^{19}$ or pentafluorobenzylbromide,$^{20}$ while heptafluorobutyric anhydride has been used for acetylation of various phenylureas. ${ }^{21}$ It complicates the analysis, which is why liquid chromatography (LC) with spectrophotometric $^{22,23}$ or fluorometric detection is usually preferred. Although diuron is not itself fluorescent, it becomes strongly fluorescent after postcolumn irradiation with UV light. $^{24,25}$ Nonetheless, these LC methods lack of specificity compared to GC methods, as their sensitivity and separation efficiency are lower. Methods using mass spectrometry (LC-MS) are the most sensitive, but they are expensive and the signal can often be affected by matrix effects. ${ }^{26}$ Capillary electrophoresis $^{27-29}$ and multivariate calibration methods ${ }^{30}$ have been also employed.

The application of chemiluminescence (CL) to the pesticides' determination has been carried out using different strategies. ${ }^{31-33}$ However, to the best of authors' knowledge, up to now the only chemiluminescent method for detecting diuron has been that proposed by Ciumasu et al. ${ }^{34}$ Those authors developed a field analysis kit for a number of pollutants, including diuron, based on immobilizing monoclonal antibodies by adsorption on a gold surface of pyramidal structures. A miniaturized flow injection analysis (FIA) system was used to transport the enzymatic tracer and the sample to the single-use chip. The determination was based on the competition between the enzyme-tracer and the diuron for the antigen-binding sites of the antibodies. The luminescence substrate was SuperSignal ${ }^{\circledR}$ ELISA Femto (luminol-enhancer $/ \mathrm{H}_{2} \mathrm{O}_{2}$ ), and the light emission was taken at 


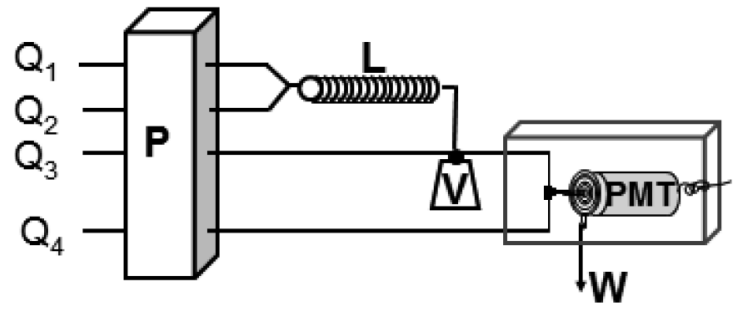

Fig. 1 Optimized flow-assembly for diuron determination. $\mathrm{Q}_{1}$, sample (1.55 mL min $\left.{ }^{-1}\right)$; $\mathrm{Q}_{2}, \mathrm{NaOH} 0.18 \mathrm{M}\left(0.75 \mathrm{~mL} \mathrm{~min}^{-1}\right)$; $\mathrm{Q}_{3}$, water $\left(12.2 \mathrm{~mL} \mathrm{~min}^{-1}\right) ; \mathrm{Q}_{4}, 2.7 \times 10^{-3} \mathrm{M} \mathrm{K}_{3} \mathrm{Fe}(\mathrm{CN})_{6}$ in $0.05 \mathrm{M}$ phosphate buffer at $\mathrm{pH} 11.5\left(1.55 \mathrm{~mL} \mathrm{~min}^{-1}\right) ; \mathrm{P}$, peristaltic pump; L, photoreactor; $\mathrm{V}$, injection valve $(995 \mu \mathrm{L})$; PMT, photomultiplier tube; W, waste.

the end of substrate incubation. The method was very sensitive (LOD $0.2 \mu \mathrm{g} \mathrm{L}^{-1}$ ) and versatile, but not suitable when high throughputs are required.

The strategy proposed in this paper is very different, as it is based on direct photoinduced chemiluminescence (PICL) of the diuron photoproducts generated by irradiation with UV light. The FIA-PICL combination provided a highly simple, fast and precise method, using a very simple and economic instrumentation..$^{35-37}$ The irradiation step was performed on-line and it can be considered as a clean, cheap and reproducible way for the derivatization of diuron. On the other hand, selectivity and sensitivity could be greatly improved with SPE systems.

\section{Experimental}

\section{Reagents and apparatus}

All solutions were prepared from analytical-grade reagents in Milli-Q water $\left(18 \mathrm{M} \Omega \mathrm{cm}^{-1}\right)$ from Millipore, Bedford, MA, provided with a fiber filter of $0.22 \mu \mathrm{m}$ pore-size. Diuron (95.5\%), glyphosate (99.2\%), terbutylazine-2-hydroxy (99.2\%), amitrol (99.9\%), monuron (99.4\%), linuron (99.7\%) and fenuron (99.6\%) were purchased from Riedel-de Haën. Chlorotoluron (99.5\%) was from Chem Service.

The FIA system used is depicted in Fig. 1. Connections were effected with a PTFE coil of $0.8 \mathrm{~mm}$ i.d. from Omnifit, and flow regulation was performed with a Gilson (Worthington, $\mathrm{OH}$ ) Minipuls 2 peristaltic pump, provided with tygon pump tubes from Restec. A laboratory-made photoreactor included PTFE tubing $(0.8 \mathrm{~mm}$ i.d. $\times 400 \mathrm{~cm})$ tightly coiled around a $15 \mathrm{~W}$ low-pressure mercury lamp (Sylvania) for germicidal use. A 6-port medium pressure injection valve (Upchurch Scientific, Model V-450) was used and the flow-cell was a flat-spiral glass tube of $1 \mathrm{~mm}$ i.d. and $3 \mathrm{~cm}$ total diameter. The photodetector package was a P30CWAD5F-29 Type 9125 photomultiplier tube (PMT) operating at $1280 \mathrm{~V}$ (Electron Tubes) and located in a laboratory-made light-tight box.

\section{Sample and standard preparation}

A $40 \mathrm{mg} \mathrm{L}^{-1}$ stock solution of diuron was prepared in $1 \%$ ethanol, by exactly weighing and dissolving $0.01 \mathrm{~g}$ of diuron in $2.5 \mathrm{~mL}$ of pure ethanol and filling with water up to $250 \mathrm{~mL}$. The stock solution was protected against light and was stable for at least a week. Working standard solutions were prepared daily by diluting in water and protecting them from light.

Water samples from different origins, namely: irrigation, ground, sea, spring, mineral and tap waters were tested. They were collected in plastic flaks at $4^{\circ} \mathrm{C}$ and analyzed before $48 \mathrm{~h}$.
In order to remove sand and other suspended solid matter, the samples were filtered over a $0.45-\mu \mathrm{m}$ membrane filter (Sartorius, Goettongen, Germany). A proper amount of diuron stock solution was spiked to $500 \mathrm{~mL}$ samples, to obtain solutions containing 5, 8, 11 and $14 \mu \mathrm{g} \mathrm{L} \mathrm{L}^{-1}$ of diuron.

The removal of interferences and preconcentration of diuron was carried out using the SPE method proposed by E. van der Heeft et al., ${ }^{38}$ with some modifications. Hence, the treatment was performed off-line using a vacuum system and solid phase cartridges Bond Elut- $\mathrm{C}_{18}$ (200 mg, Varian). In order to precondition the cartridge, we used $3.0 \mathrm{~mL}$ of methanol, $3.0 \mathrm{~mL}$ of acetone, $3.0 \mathrm{~mL}$ of methanol and $6.0 \mathrm{~mL}$ of water. After that, $500 \mathrm{~mL}$ of spiked water sample was allowed to pass through the cartridge at a flow-rate of $5 \mathrm{~mL} \mathrm{~min}{ }^{-1}$. The washing of cartridges was performed with $8 \mathrm{~mL}$ of water and next they were dried by passing air for $30 \mathrm{~min}$. Diuron was eluted by means of gravity with $2.0 \mathrm{~mL}$ of acetone and finally under vacuum. Then the solvent was evapored to dryness under a gentle stream of nitrogen at room temperature and the residue was sonicated with 8 or $10 \mathrm{~mL}$ of water for $1 \mathrm{~min}$, leading to a 62.5 - or 50 -fold preconcentration, respectively.

\section{Results and Discussion}

\section{Selection of the oxidant system}

First of all, the viability of diuron determination by direct CL from either the pesticide or its photoproducts was studied. With this aim, different oxidant systems were tested in a flow system on the basic lines of that shown in Fig. 1, but with the addition of a Y-shaped piece into $\mathrm{Q}_{4}$ channel in order to mix the oxidant and oxidation medium in situ. The sample $\left(30 \mathrm{mg} \mathrm{L}^{-1}\right.$ of diuron) was mixed with different photodegradation media (water, $\mathrm{NaOH} 0.1 \mathrm{M}$ and $\mathrm{H}_{2} \mathrm{SO}_{4} 0.1 \mathrm{M}$ ), both circulating at $1.3 \mathrm{~mL} \mathrm{~min}^{-1}$. After $46 \mathrm{~s}$ of UV irradiation, $503 \mu \mathrm{L}$ of that mixture were injected into a water carrier $\left(3.8 \mathrm{~mL} \mathrm{~min}^{-1}\right)$, which merged with the oxidant system $\left(0.8 \mathrm{~mL} \mathrm{~min}^{-1}\right)$. Experiments were carried out with and without UV irradiation in order to check the CL arising from the photoproduct.

The oxidants tested were: $\mathrm{KMnO}_{4}, \mathrm{Ce}(\mathrm{IV}), \mathrm{KIO}_{4}$ and $\mathrm{K}_{2} \mathrm{~S}_{2} \mathrm{O}_{8}$ $\left(8.0 \times 10^{-3} \mathrm{M}\right.$ except for $\mathrm{KMnO}_{4}$, which was $\left.1.4 \times 10^{-3} \mathrm{M}\right)$ in $\mathrm{H}_{2} \mathrm{SO}_{4} 2 \mathrm{M}$, and $\mathrm{KIO}_{4}, \mathrm{~K}_{2} \mathrm{~S}_{2} \mathrm{O}_{8}, \mathrm{~K}_{3} \mathrm{Fe}(\mathrm{CN})_{6}, N$-bromosuccinimide and $\mathrm{H}_{2} \mathrm{O}_{2}\left(8.0 \times 10^{-3} \mathrm{M}\right.$ except for $\mathrm{N}$-bromosuccinimide, which was $\left.5.0 \times 10^{-2} \mathrm{M}\right)$ in $\mathrm{NaOH} 2 \mathrm{M}$.

a) With the lamp off, only a weak signal was obtained with $\mathrm{K}_{3} \mathrm{Fe}(\mathrm{CN})_{6}(320 \mathrm{~Hz}$ using $\mathrm{NaOH} 0.1 \mathrm{M}$ as photodegradation medium)

b) No signal was obtained with $\mathrm{KIO}_{4}$ or $\mathrm{K}_{2} \mathrm{~S}_{2} \mathrm{O}_{8}$ in acid medium.

c) With $\mathrm{H}_{2} \mathrm{O}_{2}$ and $\mathrm{K}_{2} \mathrm{~S}_{2} \mathrm{O}_{8}$ in a basic medium, the signal was very weak and similar in all the irradiation media tested.

d) With $\mathrm{N}$-bromosuccinimide and $\mathrm{KIO}_{4}$ in a basic medium, the CL signal always remained below $1 \mathrm{kHz}$.

e) The strongest signals were obtained with $\mathrm{KMnO}_{4}$, using water as photoreaction medium $(10.2 \mathrm{kHz})$, and with $\mathrm{Ce}(\mathrm{IV})(7.0 \mathrm{kHz})$ and $\mathrm{K}_{3} \mathrm{Fe}(\mathrm{CN})_{6}(17.9 \mathrm{kHz})$ with $\mathrm{NaOH}$ as UV irradiation medium.

On the basis of these results, the oxidant systems mentioned in e) were chosen for a more detailed study. Their concentrations were varied in the following ranges: $5 \times 10^{-5}-1.8 \times 10^{-3} \mathrm{M}$ for permanganate, $5 \times 10^{-4}-1.2 \times 10^{-2} \mathrm{M}$ for ferricyanide and $5 \times 10^{-5}-5 \times 10^{-2} \mathrm{M}$ for $\mathrm{Ce}(\mathrm{IV})$. As can be observed in Fig. 2, the CL signal decreased dramatically with permanganate concentration, probably due to auto-absorption phenomena. Ce(IV) provided a low signal, so it was discarded and the 


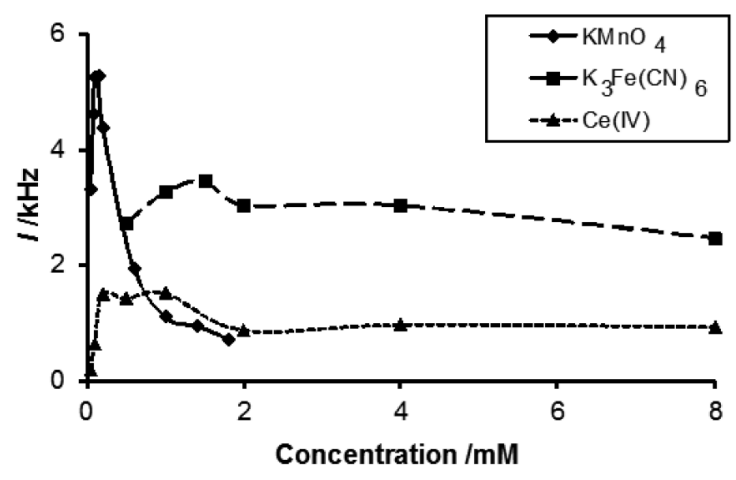

Fig. 2 Influence of oxidants concentration on CL signal $(I)$ of $7.5 \mathrm{mg} \mathrm{L}^{-1}$ diuron. Photoreaction media: water $\left(\mathrm{KMnO}_{4}\right)$ or $\mathrm{NaOH}$ $0.1 \mathrm{M}\left(\mathrm{Ce}(\mathrm{IV})\right.$ and $\left.\mathrm{K}_{3} \mathrm{Fe}(\mathrm{CN})_{6}\right)$. Oxidation media: $\mathrm{H}_{2} \mathrm{SO}_{4} 2 \mathrm{M}\left(\mathrm{KMnO}_{4}\right.$ and $\mathrm{Ce}(\mathrm{IV}))$ or $\mathrm{NaOH} 2 \mathrm{M}\left(\mathrm{K}_{3} \mathrm{Fe}(\mathrm{CN})_{6}\right)$. Flow rates $\left(\mathrm{mL} \mathrm{min}^{-1}\right)$ carrier/oxidant and oxidation medium: $3.8 / 0.8 \quad\left(\mathrm{KMnO}_{4}\right.$ and $\left.\mathrm{K}_{3} \mathrm{Fe}(\mathrm{CN})_{6}\right)$ or 5.2/1.1 (Ce(IV)).

influence of the oxidation media was only studied for permanganate and ferricyanide.

When ferricyanide $1.5 \times 10^{-3} \mathrm{M}$ was employed, $\mathrm{NaOH}$ concentrations between 0.01 and $4.0 \mathrm{M}$ were tested as oxidation media. The signal was found to rise exponentially as the concentration of the base fell until $0.08 \mathrm{M}$; and then the signal levelled off. The reason for that trend was that $\mathrm{NaOH}$ concentration in the detection cell was determined essentially by the $\mathrm{NaOH}$ injected as photodegradation medium $(0.1 \mathrm{M})$, so the effect of the hydroxide employed as oxidation medium was insignificant. Bear in mind that, it was impossible to study the influences of oxidation and photodegradation media independently; different buffers, namely, glycine; $\mathrm{Na}_{2} \mathrm{HPO}_{4} / \mathrm{NaOH} ; \quad \mathrm{Na}_{2} \mathrm{~B}_{4} \mathrm{O}_{7} / \mathrm{NaOH} ; \quad \mathrm{Na}_{2} \mathrm{CO}_{3} / \mathrm{NaHCO}_{3} \quad$ and $\mathrm{NH}_{4} \mathrm{Cl} / \mathrm{NH}_{3}$, were tested as oxidation media, with the aim that the $\mathrm{pH}$ in detection cell was not affected by photoreaction medium. The best results, for $2.5 \mathrm{mg} \mathrm{L}^{-1}$ diuron, were those obtained with a $\mathrm{Na}_{2} \mathrm{HPO}_{4} / \mathrm{NaOH}$ buffer at $\mathrm{pH} 11.5$ introduced into both oxidation medium and carrier channels.

For $1.5 \times 10^{-3} \mathrm{M}$ of permanganate, the following acids were tested employing a $2 \mathrm{M}$ concentration (signals in $\mathrm{Hz}$ in brackets): $\mathrm{H}_{2} \mathrm{SO}_{4}$ (4516), $\mathrm{HCl}$ (4140), $\mathrm{HClO}_{4}$ (4520), $\mathrm{HNO}_{3}$ (3030), $\mathrm{H}_{3} \mathrm{PO}_{4}$ (4412) and $\mathrm{CH}_{3} \mathrm{COOH}$ (1220). Further studies were carried out using the three acids which provided the strongest signals employing 5 different concentrations of each over the $0.5-4.0 \mathrm{M}$ range. Analogous signals were obtained with sulfuric acid $2 \mathrm{M}$ and perchloric acid $3 \mathrm{M}$ (around $6500 \mathrm{~Hz}$ ) and somewhat lower values for phosphoric acid (around $5600 \mathrm{~Hz}$ ).

According to the results obtained, the use of permanganate in an acid medium was abandoned because the analytical signals obtained were around three times lower than those for ferricyanide in basic medium.

\section{Effect of photodegradation medium and irradiation time}

The $\mathrm{pH}$ buffers reported were tested as photodegradation media, but none of them increased the signal when compared with $\mathrm{NaOH}$. Base concentrations between 0.05 and $0.25 \mathrm{M}$ were also tested ( $2 \mathrm{mg} \mathrm{L}^{-1}$ diuron) and the maximum signal was obtained with $0.17 \mathrm{M} \mathrm{NaOH}$.

The effect of the irradiation time on the CL signal was studied by changing the flow rate of the diuron solution and photodegradation medium through the irradiation zone.

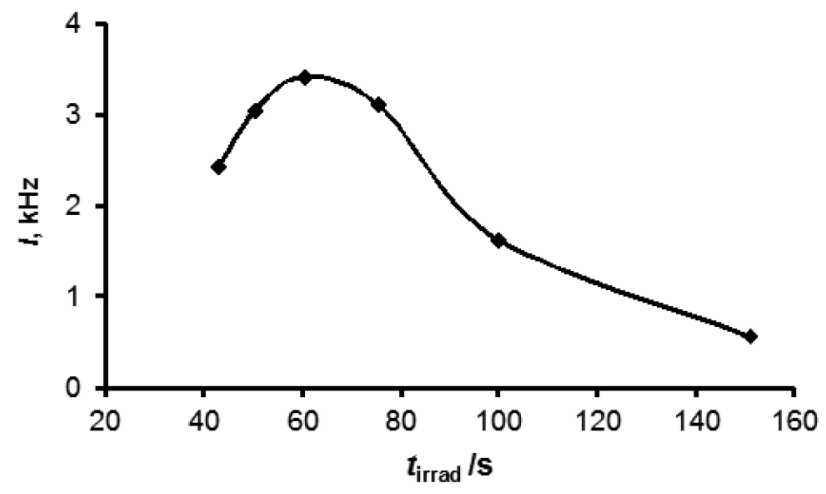

Fig. 3 Influence of the irradiation time $\left(t_{\text {irrad }}\right)$ on CL signal $(I)$ of $2 \mathrm{mg} \mathrm{L}^{-1}$ diuron.

Figure 3 shows that too short irradiation times caused insufficient conversion of the diuron into its photoproducts, and, too long times led to the formation of photoproducts that were not chemiluminescent. The optimum irradiation time was found to be around $60 \mathrm{~s}$ (diuron and $\mathrm{NaOH}$ flowing at $2 \mathrm{~mL} \mathrm{~min}^{-1}$ ).

\section{Effects of sensitizers and surfactants}

A large number of substances are capable of acting as potential photosensitizers and/or CL sensitizers. The following substances and concentrations were tested: ethanol 10 and $40 \%$, acetone $1 \%$, acetonitrile $30 \%$; a mixture of $30 \%$ acetonitrile and $1 \%$ acetone; 1,4-dioxane 10\%; formic acid 1\%; 2-propanol 40\%; sodium sulfite, quinine, 8-hydroxyquinoline and fluorescein $2 \times 10^{-4} \mathrm{M}$; and eosin yellowish, riboflavin and rhodamine $\mathrm{B}$ $10^{-4} \mathrm{M}$.

Compounds that provide organized media and give structural rigidity to the medium can increase the half-life of the emitting species. Hence, the effect of the following substances was assayed: $\beta$-cyclodextrin $0.46 \%$ and anionic, cationic and neutral surfactants: sodium dodecyl sulfate, $0.2 \%$ and $1.38 \%$; hexadecyltrimethylammonium bromide, $0.03 \%$ and $0.2 \%$; Triton X-100, $0.04 \%$ and $0.13 \%$.

To carry out the study, we added a confluence point to the photodegradation medium channel so that the sensitizer under study, flowing at $0.5 \mathrm{~mL} \mathrm{~min}^{-1}$, could mix with the photoreaction medium $\left(\mathrm{NaOH} 0.34 \mathrm{M}\right.$ at $\left.0.5 \mathrm{~mL} \mathrm{~min}{ }^{-1}\right)$.

The use of sensitizers or organized media was finally discarded due to the fact that none of the tested substances improved the analytical signal.

\section{Optimization of hydrodynamic parameters and temperature}

In order to study the effect of the temperature in the determination of diuron, we submerged the sample loop and two $1.5 \mathrm{~m}$ sections of teflon tube $(0.8 \mathrm{~mm}$ i.d.) located in the carrier (immediately prior to the injection valve) and in the oxidant channel in a water bath. The signals recorded at 20, 43, 58 and $73^{\circ} \mathrm{C}$, remained constant between 20 and $43^{\circ} \mathrm{C}$ and weakened at both higher and lower temperatures; room temperature was selected for further work.

The apparatus was simplified by removing the confluence between the ferricyanide and the buffer and preparing both together, leaving the apparatus as shown in Fig. 1. As many of the experimental variables had changed since the beginning of the work, ferricyanide concentration was reoptimized between $6.54 \times 10^{-4}$ and $1.6 \times 10^{-3} \mathrm{M}$ and was finally set at $1.4 \times 10^{-3} \mathrm{M}$. With the flow rate ratio kept constant $\left(Q_{3} / Q_{4}=3\right)$, the total CL 
reaction flow rate $\left(Q_{3}+Q_{4}\right)$ was then varied between 5.1 and $14.6 \mathrm{~mL} \mathrm{~min}{ }^{-1}$. The signal increased throughout the range studied, although minimally from $11.8 \mathrm{~mL} \mathrm{~min}^{-1}$, and a flow rate of $13.2 \mathrm{~mL} \mathrm{~min}^{-1}$ (9.9 and $3.3 \mathrm{~mL} \mathrm{~min}^{-1}$ for carrier and oxidant, respectively) was finally chosen.

The volume of injection was varied between 508 and $1488 \mu \mathrm{L}$. The signal increased initially, and then remained constant from $995 \mu \mathrm{L}$ onwards. That value was selected to prevent a negative effect on the throughput and unnecessary sample consumption.

\section{Reoptimization of the main variables}

In order to avoid unnecessary dilutions of diuron, we modified the sample/photoreaction medium $\left(Q_{1} / Q_{2}\right)$ flow rate ratio. The values finally selected were $\mathrm{NaOH}$ concentration of $0.18 \mathrm{M}$ and flow rates of 1.55 and $0.75 \mathrm{~mL} \mathrm{~min}^{-1}$ for the sample and hydroxide, respectively (irradiation time of $53 \mathrm{~s}$ ).

Potassium ferricyanide concentration was varied between $1.2 \times 10^{-3}-4 \times 10^{-3} \mathrm{M}$ and the value finally selected was $2.7 \times 10^{-3} \mathrm{M}$. The total flow $\left(Q_{3}+Q_{4}\right)$ was varied between 13.2 and $16.7 \mathrm{~mL} \mathrm{~min}{ }^{-1}$ and $16.1 \mathrm{~mL} \mathrm{~min}^{-1}\left(Q_{3}=12.2 \mathrm{~mL} \mathrm{~min}^{-1}\right.$ and $Q_{4}=3.9 \mathrm{~mL} \mathrm{~min}^{-1}$ ) was selected. The experiment was carried out with a $1 \mathrm{mg} \mathrm{L}^{-1}$ solution of diuron.

Since when the buffer used as carrier was replaced by water, only a decrease of $4.8 \%$ in the CL signal was observed, water was selected in order to achieve a cleaner system and, to avoid any loss of buffer capacity. The buffer concentration in the oxidant solution was doubled $(0.05 \mathrm{M})$, which did not affect the analytical signal.

\section{Diuron Photodegradation Mechanism}

Irradiation can break down the molecules (photolysis) or induce a number of changes such as photocyclization, photoisomerization, photooxidation and photoreduction. ${ }^{39}$

Diuron photolysis has been studied by various authors, particularly in relation to its application in water treatment processes to remove contamination by this pesticide. In the environment, diuron is mainly photolyzed by sunlight. In the laboratory, UV light has been used to generate more easily detectable photoproducts, ${ }^{39}$ as in the present study. In both cases it is of interest to discover the nature of the products that are generated, which can sometimes be more toxic than diuron itself.

The absorption spectrum of diuron ${ }^{8}$ in an aqueous solution presents two main peaks, at around 247 and $284 \mathrm{~nm}$. Following irradiation with $254 \mathrm{~nm}$ UV light, the absorption increases between 270 and $310 \mathrm{~nm}$ and decreases between 240 and $260 \mathrm{~nm}$, but no new absorption bands are observed.

Tanaka et $a l .{ }^{40}$ compared diuron photolysis products employing sunlight and UV lamps. In both cases, the main products identified were hydroxylated compounds in the ring, as a result of a chlorine atom being replaced by $-\mathrm{OH}$ at the meta or para position, giving 3-(4-chloro-3-hydroxyphenyl)-1,1-dimethylurea and 3-(3-chloro-4-hydroxyphenyl)-1,1-dimethylurea, respectively. These same compounds were mentioned as the main photoproducts by Jirkovský et al. ${ }^{8}$ when an aqueous solution of diuron was irradiated with $254 \mathrm{~nm}$ light. According to the latter authors, at $254 \mathrm{~nm}$ the hydroxylated product abounds more in the para position (90\% of the conversion) whereas the meta position is more abundant at longer wavelengths (365 and $334 \mathrm{~nm}$ ). They also observed that the formation of these compounds did not depend on the presence of oxygen and only occurred in aqueous solution. The minor products of these photolysis reactions are compounds produced by demethylation and oxidation of the methyl groups, chlorobiphenyl derivatives and unidentified polar products. ${ }^{40}$

Photoreduction is generally not very efficient in pure water, but it can be the main reaction in the presence of methanol or other alcohols, which can act as reducing agents, modifying reactivity through hydrogen transfer to the photoactive species. For instance, it has been found that the presence of small percentages of methanol gave rise to photoreduction to monuron ${ }^{41}$ or to 3-(3-chlorophenyl)-1,1-dimethylurea. ${ }^{8}$ However, it is very unlikely that this is the phototransformation mechanism in the proposed system, since the highest percentage of ethanol used was only $0.1 \%$, whereas the methanol concentrations employed in the studies above cited were around 3-4\%; moreover, additional assays showed that in the presented system the monuron signal was very small.

\section{Method Validation}

\section{Analytical characteristics}

The range of applicability of the FIA method was 0.1 $4.0 \mathrm{mg} \mathrm{L}^{-1}$, and the mean equation for seven calibration graphs, obtained in different days with new solutions, was $\log I=$ $(1.504 \pm 0.015) \log C+(3.69 \pm 0.04), \quad r^{2}=(0.9973 \pm 0.0008)$, where $I$ is the intensity in $\mathrm{Hz}$ and $C$ the concentration of diuron in $\mathrm{mg} \mathrm{L}^{-1}$. The inter-day reproducibility of the proposed method was determined from the above-mentioned experiment and the RSD of the slope was found to be $1.0 \%$. The detection limit $\left(20 \mu \mathrm{g} \mathrm{L}^{-1}\right)$ was defined as the lowest diuron concentration that gave a signal equal to or greater than three times the mean base line. The RSD of a series of 21 injections of a $0.4 \mathrm{mg} \mathrm{L}^{-1}$ solution of diuron was $3.1 \%$, and the throughput was $75 \mathrm{~h}^{-1}$.

In order to increase the sensitivity of the method, it was decided to employ SPE, which allows both the preconcentration of diuron and the cleaning of the samples. The SPE cartridges chosen were $\mathrm{C}_{18}$, which are widely used for phenylurea preconcentration, since polar substances and ions are not retained. Methanol and acetone showed no differences in the achieved recovery percentage, but acetone was chosen because of its greater volatility and consequent greater ease of elimination. The procedure finally selected is described in the section on Sample and standard preparation.

The analytical performance of the method proposed was significantly improved by combining FIA with SPE. Hence, the dynamic range obtained was $1.5-30 \mu \mathrm{g} \mathrm{L}^{-1}$ (higher concentrations were not tested). The repeatability was studied using a $8 \mu \mathrm{g} \mathrm{L}^{-1}$ diuron $(n=8, \operatorname{RSD}=4.5 \%)$. Likewise, the detection limit was significantly reduced achieving a value of $0.4 \mu \mathrm{g} \mathrm{L}^{-1}$.

The tolerance of the proposed method to potential interferents (Tables 1 and 2) was studied. The interferent concentration was gradually reduced until the relative error, compared to the signal in the absence of the interferent, was below $5 \%$. Some of the tested ions, such as $\mathrm{HCO}_{3}^{-}, \mathrm{NO}_{3}{ }^{-}, \mathrm{Ca}^{2+}$ and $\mathrm{Mg}^{2+}$, which are normally very abundant in environmental samples, and amitrol, which is formulated together with diuron, exhibited a significant interference.

The removal of interferents by SPE was demonstrated by passing $50 \mathrm{~mL}$ of solutions containing $0.08 \mathrm{mg} \mathrm{L}^{-1}$ of diuron and different interferents. As can be deduced from the results shown in Table 3, the selectivity of the method proposed was significantly increased.

\section{Application to water samples}

Finally, the proposed SPE-FIA method was applied to the determination of diuron in six samples of water from different 
Table 1 Study of the interfering effect of compounds present in water and other phenylurea pesticides for $0.4 \mathrm{mg} \mathrm{L}^{-1}$ of diuron

\begin{tabular}{lcc}
\hline Interference & Concentration $/ \mathrm{mg} \mathrm{L}^{-1}$ & Error, \% \\
\hline $\mathrm{Na}^{+}$ & $1000^{\mathrm{a}}$ & 1.2 \\
$\mathrm{Cl}^{-}$ & $1540^{\mathrm{a}}$ & 1.2 \\
$\mathrm{~K}^{+}$ & 800 & 0.9 \\
$\mathrm{Ca}^{2+}$ & 15 & -1.0 \\
$\mathrm{Mg}^{2+}$ & 50 & 1.2 \\
$\mathrm{NH}_{4}{ }^{+}$ & $100^{\mathrm{a}}$ & -3.3 \\
$\mathrm{SO}_{4}{ }^{2-}$ & $1000^{\mathrm{a}}$ & 5.0 \\
$\mathrm{CH}_{3} \mathrm{COO}^{-}$ & $100^{\mathrm{a}}$ & -1.1 \\
$\mathrm{H}_{2} \mathrm{PO}_{4}^{-}$ & $100^{\mathrm{a}}$ & 1.6 \\
$\mathrm{HCO}_{3}^{-}$ & 20 & 1.8 \\
$\mathrm{NO}_{2}^{-}$ & 1 & 2.4 \\
$\mathrm{NO}_{3}^{-}$ & 1 & -2.4 \\
Urea $_{\text {Monuron }}^{-}$ & 30 & -1.2 \\
$\mathrm{Linuron}_{\mathrm{Chlorotoluron}}$ & 0.1 & -5.2 \\
Fenuron & 0.8 & 5.2 \\
\hline
\end{tabular}

a. Maximum assayed concentration.

Table 2 Interfering effect of substances commonly present in diuron commercial formulations $\left(0.4 \mathrm{mg} \mathrm{L}^{-1}\right.$ of diuron)

\begin{tabular}{lccc}
\hline Interference & $\begin{array}{c}\text { [Interference]/ } \\
\text { [diuron] in } \\
\text { commercial } \\
\text { formulation }\end{array}$ & $\begin{array}{c}\text { [Interference]/ } \\
\text { [diuron] assayed }\end{array}$ & $\begin{array}{c}\text { Error, } \\
\%\end{array}$ \\
\hline $\mathrm{NH}_{4} \mathrm{SCN}$ & 1.8 & $10^{\mathrm{a}}$ & -4 \\
Glyphosate & 0.82 & $10^{\mathrm{a}}$ & 5.0 \\
Terbuthylazine & 1 & Saturated solution & -2.6 \\
Amitrol & 1.9 & 0.63 & 4.6 \\
\hline
\end{tabular}

a. Maximum assayed concentration.

sources: spring, ground, mineral, irrigation, sea and tap waters As shown in Table 4, recovery rates ranged from 90.2 to $112.5 \%$ for samples spiked with diuron at four different concentrations between 5 and $14 \mu \mathrm{g} \mathrm{L}^{-1}$.

The acceptable range for recoveries in water samples is usually set between 70 and $110 \%$, with a maximum permitted RSD of $20 \% .{ }^{42}$ Thus, it can be considered that the analytical performance of the proposed method was successful, since only the recovery for the irrigation water, a highly complex sample, was beyond that interval (recovery $112.5 \%$ ). On the other hand, the RSD values achieved were under $8 \%$ in all cases.

\section{Conclusions}

The use of light as a "reagent" has allowed the detection of diuron, which presents no native CL, thanks to the chemiluminescent properties of the photofragments generated by irradiation with UV light. The proposed method was based on oxidation of the photoproducts with potassium ferricyanide in a basic medium.

The FIA-PICL combination provides a highly fast and precise determination, using a very simple and economic instrumentation. The selectivity and sensitivity of the method was effectively increased by using $\mathrm{C}_{18}$ cartridges. As a result, the determination of diuron at concentrations as low as a few $\mu \mathrm{g} \mathrm{L}^{-1}$ (LOD $0.4 \mu \mathrm{g} \mathrm{L}^{-1}$ ) in waters from different sources became possible.
Table 3 Interfering effect after SPE pretreatment for $0.08 \mathrm{mg} \mathrm{L}^{-1}$ of diuron

\begin{tabular}{ccc}
\hline Interference & Concentration $/ \mathrm{mg} \mathrm{L}^{-1}$ & Error, \% \\
\hline $\mathrm{Ca}^{2+}$ & 500 & -0.9 \\
$\mathrm{Mg}^{2+}$ & 100 & -2.6 \\
$\mathrm{HCO}_{3}^{-}$ & 100 & -5.0 \\
$\mathrm{NO}_{2}^{-}$ & 10 & -3.9 \\
$\mathrm{NO}_{3}^{-}$ & 100 & -0.5 \\
$\mathrm{Amitrol}$ & $0.152^{\mathrm{a}}$ & 5.4 \\
\hline
\end{tabular}

a. It was the maximum concentration assayed, which corresponded to the common ratio in commercial preparations (1.9:1).

Table 4 Determination of diuron in water samples

\begin{tabular}{|c|c|c|c|c|c|c|}
\hline \multirow{2}{*}{$\begin{array}{l}\text { Diuron } \\
\text { added/ } \\
\mu \mathrm{g} \mathrm{L}^{-1}\end{array}$} & \multicolumn{6}{|c|}{ Diuron found $/ \mu \mathrm{g} \mathrm{L}^{-1}$} \\
\hline & $\begin{array}{c}\text { Mineral } \\
\text { water }\end{array}$ & $\begin{array}{c}\text { Tap } \\
\text { water }\end{array}$ & Seawater & $\begin{array}{c}\text { Ground } \\
\text { water }\end{array}$ & $\begin{array}{l}\text { Spring } \\
\text { water }\end{array}$ & $\begin{array}{c}\text { Irrigation } \\
\text { water }\end{array}$ \\
\hline 5 & 4.47 & 4.27 & 5.94 & 4.42 & 5.56 & 5.78 \\
\hline 8 & 7.87 & 7.48 & 8.41 & 7.82 & 8.58 & 9.13 \\
\hline 11 & 11.46 & 9.87 & 11.07 & 11.52 & 11.21 & 12.4 \\
\hline 14 & 13.37 & 12.89 & 14.78 & 12.84 & 14.72 & 15.05 \\
\hline $\begin{array}{l}\text { Mean } \\
\text { recovery, \% }\end{array}$ & 96.9 & 90.2 & 107.5 & 95.6 & 106.4 & 112.5 \\
\hline RSD, \% & 6.1 & 3.5 & 7.8 & 7.2 & 3.9 & 3.5 \\
\hline
\end{tabular}

The maximum permitted concentration of diuron in drinking water varies considerably. In Canada it has been set at $150 \mu \mathrm{g} \mathrm{L}^{-1}$, in Australia at $30 \mu \mathrm{g} \mathrm{L}^{-1}$, and the Environmental Protection Agency (EPA) has set $70 \mu \mathrm{g} \mathrm{L}^{-1}$ as the permissible limit of diuron in water for human consumption. ${ }^{42}$ Although the LOD achieved without the SPE step $\left(20 \mu \mathrm{g} \mathrm{L}^{-1}\right)$ could made this method suitable for routine control of this pesticide, it was worth using the combination FIA-SPE, since it was possible to increase the selectivity of the method reducing considerably the LOD, until a value of $0.4 \mu \mathrm{g} \mathrm{L}^{-1}$, close to the European Union (EU) maximum levels, established in 0.1 and $0.5 \mu \mathrm{g} \mathrm{L}^{-1}$ for individual compounds and total pesticides, respectively (98/83/CE).

To the authors' knowledge only one of the reported methods for the determination of diuron has been based on CL. ${ }^{34}$ It was highly selective and sensitive (LOD $0.2 \mu \mathrm{g} \mathrm{L}^{-1}$ ), but it was time-consuming and very expensive, as it was based on immobilizing monoclonal antibodies on a gold surface of a single-use chip, which required one to carry out several steps (filling, washing, incubation...) before starting the measurement.

\section{Acknowledgements}

The authors would like to thank the Ministry of Education and Science of Spain for financial support: Project CTM2006-11991 and FEDER funds.

We would like also to thank the R\&D\&I Linguistic Assistance Office, Universidad Politécnica de Valencia (Spain), for translating this paper.

\section{References}

1. C. De Liñan, "Farmacología Vegetal. Compendio de las 
Materias Activas más Interesantes en Fisiopatología. Su Toxicidad y Empleo", 1997, ed. Agrotécnicas, Madrid.

2. A. R. Fernandez-Alba, M. D. Hernando, L. Piedra, and Y. Chisti, Anal. Chim. Acta, 2002, 456, 303.

3. C. Tixier, P. Bogaerts, M. Sancelme, F. Bonnemoy, L. Twagilimana, A. Cuer, J. Bohatier, and H. Veschambre, Pest Manage. Sci., 2002, 56, 455.

4. A. Negri, C. Vollhardt, C. Humphrey, A. Heyward, R. Jones, G. Eaglesham, and K. Fabricius, Mar. Pollut. Bull., 2005, 51, 370 .

5. I. K. Konstantinou and T. A. Albanis, Environ. Int., 2004, 30, 235.

6. S. Salvestrini, P. Di Cerbo, and S. Capasso, Chemosphere, 2002, 48, 69 .

7. D. Simon, S. Helliwell, and K. Roberts, Anal. Chim. Acta, 1998, $360,1$.

8. J. Jirkovský, V. Faure, and P. Boule, Pest. Sci., 1997, 50, 42.

9. K. Okumura, Chemosphere, 2002, 48, 43.

10. R. M. Ramírez-Zamora and R. Seux, Rev. Sci. Eau., 1999, $12 / 3,545$.

11. Office of Environmental Health Hazard Assessment http:// www.oehha.ca.gov/prop65/out_of_date/53102P65notice.html.

12. European Commission, "Establishing the List of Priority Pollutants in the Field of Water Policy and Amending Directive 2000/60/EC", Official Journal of the European Communities, Decision n. 2455/2001/EC of the European Parliament and of the Council, L 331/1, 2001.

13. C. F. Poole, Trends Anal. Chem., 2003, 22(6), 362.

14. G. Gatidoua, A. Kotriklaa, N. S. Thomaidisb, and T. D. Lekkas, Anal. Chim. Acta, 2005, 528, 89.

15. M. Guardia-Rubio, A. Ruiz-Medina, M. I. Pascual-Reguera, and M. L. Fernandez-de-Cordova, Microchem. J., 2007, 85(2), 257.

16. E. Ayano, Y. Okada, C. Sakamoto, H. Kanazawa, T. Okano, M. Ando, and T. Nishimura, J. Chromatogr., A, 2005, 1069, 281.

17. L. Brossa, E. Pocurull, F. Borrull, and R. M. Marcé, Chromatographia, 2004, 59(7/8), 419.

18. J. F. Lawrence, C. Van Buuren, U. A. T. Brinkman, and R. W. Frei, J. Agric. Food Chem., 1980, 28, 630.

19. A. C. Gerecke, C. Tixier, T. Bartels, R. P. Schwarzenbach, and S. R. Müller, J. Chromatogr., A, 2001, 930, 9.

20. A. Scheyer, O. Briand, S. Morville, P. Mirabel, and M. Millet, Anal. Bioanal. Chem., 2007, 387, 359.

21. K. Wittke, H. Hajimiragha, L. Dunemann, and J. Begerow, LaborPraxis, 2000, 24(9), 62.
22. V. I. Boti, V. A. Sakkas, and T. A. Albanis, J. Chromatogr., A, 2007, 1146(2), 139.

23. "Water Quality. Determination of Selected Plant Treatment Agents. High Performance Liquid Chromatography (HPLC) with UV Detection after Solid-liquid Extraction", EN ISO 11369:1997, 21, 1993.

24. A. R. Mughari, P. Parrilla-Vázquez, and M. Martínez-Galera, Anal. Chim. Acta, 2007, 593(2), 157.

25. A. Muñoz-de-la-Peña, M. C. Mahedero, and A. Bautista-Sánchez, J. Chromatogr., A, 2002, 950(1-2), 287.

26. H. Berrada, G. Font, and J. C. Moltó, Chromatographia, 2001, 54, 253.

27. M. B. Barroso, L. N. Konda, and G. Morovjan, J. High Resolut. Chromatogr., 1999, 22(3), 171.

28. H. Süsse and H. Müller, J. Chromatogr., A, 1996, 730, 337.

29. R. Rodríguez, Y. Picó, G. Font, and J. Mañes, Electrophoresis, 2010, s, 2010.

30. M. Martínez Galera, J. L. Martínez Vidal, A. Garrido Frenich, and P. Parrilla, Analyst, 1994, 119, 1189.

31. L. Gámiz-Gracia, A. M. García-Campaña, J. J. Soto-Chinchilla, J. F. Huertas-Pérez, and A. González-Casado, Trends Anal. Chem., 2005, 24, 927.

32. X. Wang, J. M. Lin, M. L. Liu, and X. L. Cheng, Trends Anal. Chem., 2009, 28(1), 75.

33. J. L. López-Paz and M. Catalá-Icardo, Anal. Lett., in press.

34. I. M. Ciumasu, P. M. Krämer, C. M. Weber, G. Kolb, D. Tiemann, S. Windisch, I. Frese, and A. A. Kettrup, Biosens. Bioelectron., 2005, 21(2), 354.

35. J. R. Albert García, M. Catalá Icardo, and J. Martínez Calatayud, Talanta, 2006, 69, 608.

36. J. L. López-Paz and M. Catalá-Icardo, Anal. Chim. Acta, 2008, 625, 173.

37. J. L. López-Paz, M. Catalá-Icardo, and B. Antón-Garrido, Anal. Bioanal. Chem., 2009, 394, 1073.

38. E. van der Heeft, E. Dijkman, R. A. Baumann, and E. A. Hogendoorn, J. Chromatogr., A, 2000, 879, 39.

39. M. Catalá-Icardo and J. Martínez-Calatayud, Crit. Rev. Anal. Chem., 2008, 38, 118.

40. F. S. Tanaka, B. L. Hoffer, and R. G. Wein, Toxicol. Environ. Chem., 1986, 86, 261.

41. G. Durand, D. Barceló, J. Albaiges, and M. Mansour, Toxicol. Environ. Chem., 1991, 31 - 32, 55.

42. D. J. Hamilton, Á. Ambrus, R. M. Dieterle, A. S. Felsot, C. A. Harris, P. T. Holland, A. Katayama, N. Kurihara, J. Linders, J. Unsworth, and S. S. Wong, Pure Appl. Chem., 2003, 75(8), 1123. 